\section{Accounting truth and îts assurance in entitios from the Republic of Moldova}

Viorel ȚURCANU Academy of Economic Studies of Moldova, E-mail: vturcanu@mail.ru

Irina GOLOCIALOVA, Academy of Economic Studies of Moldova, E-mail: monomah5@yandex.ru

\section{Alsstract}

The multiple users will not be able to make correct decisions, unless the information provided by accounting is exact and transparent. Otherwise we cannot state that it communicates the accounting truth with regard to the activity of a company. The accounting truth is determined by several factors, like the accounting technique, the principles and the qualitative characteristics, the accounting normalization and the audit.

The objective of the study is to provide a general analysis of these factors, as well as to investigate the manner in which these support the assurance of the accounting truth in the Republic of Moldova (RM) in the context of the IFRS concept of true and fair view, also relying on practical examples from the banking system.

The results of the study show that the accounting truth in RM entities is ensured to a large extent, due to the positive impact of these factors. At the same time, there is still room for improvement in theoretical matters of accounting and financial reporting, as well as for the development of the accounting legal framework, with the purpose of expanding the financial analysis potential of the disclosed information.

The situation of the banking system shows that, if no adequate attention is paid to the operative and strategic analysis of the financial position and results, including based on audit, economically destructive phenomena can take place, both at entity-level, and at country-level.

Keywords: Accounting truth, accounting technique, qualitative characteristics, normalisation, audit control.

JEL Classification: M 41; M 11; G21.

To cite this article:

Țurcanu, V. and Golocialova, I. (2016), Accounting truth and its assurance in entities from the Republic of Moldova, Audit

Financiar, vol. XIV, no. 7(139)/2016, pp. 771-782, DOI:

10.20869/AUDITF/2016/139/771

To link to this article:

http://dx.doi.org/10.20869/AUDITF/2016/139/771 


\section{Introduction}

At the current stage, the financial information plays a significant role in the management of the entity, as valuable decisions are made to a large extent based on data provided by accounting. At the same time, it is equally important that the disclosed data are fair. Out of these reasons, British researchers developed the financial reporting concept called in Romanian „reprezentare exactă" and in English "true and fair view". The first component of the phrase has a quantitative and formalised orientation, while the second one - a psychological, ethical and moral, i.e. a non-formalised orientation (Gray, Coenberg and Cordon, 1993).

The concept is also recommended by the EU Directive 2013/34/EU, from June $26^{\text {th }} 2013$, translated in the Romanian version with the French inspired „imagine fidelă" (Colasse, 1997). As such, art. 4(3), states that "the annual financial statements shall give a true and fair view of the [...] financial position and profit or loss" (Directive 2013/34/EU). At the same time, we notice that the meaning of the true and fair view in the sense of the Directive is not quite the same with the meaning of the concept in IFRS, as paragraph (22) of the Directive emphasizes the fact that "the recognition and measurement of some items in financial statements are based on estimates, judgments and models rather than exact depictions". This is natural, as the concept does not imply the existence of rules and requirements in the preparation of financial reporting.

After examining the meaning of the above mentioned concept, we consider that its core and role are better described in Romania by the phrase "accounting truth" (Ro. „adevărul contabil”) (Colasse, 2009), employed in the present paper. The Romanian Lexicon defines the truth as "that which reflects the reality, what exists or happened in reality", which makes the truth (Ro: „adevărul”) a wider notion than the true and fair view (Ro. „reprezentarea exactă”).

The truth about the entity, as provided by accounting, is disclosed in the financial statements, prepared based on data regarding economic events during the disclosure period, and confirmed by the auditors. As such, interested users are sure that the information provided is veridical and the decisions based on this information are correct. Basically, a piece of information is veridical if it allows users to identify a concrete object or event from the economic life of the entity. It is however more complicated when knowledge on the overall object of accounting becomes necessary - the activity of the entity and the way in which the entity assures the true and fair view. For this, accounting models the processes of the entity, based on symbols; it observes the qualitative characteristics of the financial information; it applies the established accounting rules. The Conceptual Framework for Financial Reporting (The Conceptual Framework, 2010), emphasises the fact that, in order to deliver a true and fair view, a description must observe three characteristics: it must be complete, neutral and free of error.

Obviously, perfection can seldom be reached, but the accounting truth is grounded by principles which allow us to believe that the disclosed information describes the reality of the economic events, at the level of the entity. In this context, we need to mention the fact that maximizing the quality of the information should be the main objective of accounting.

Yet, the information disclosed in the entity's financial reporting can be considered veridical only if its truthfulness is confirmed by an audit firm, when auditing becomes an important factor in assuring the accounting truth.

The analysis of the accounting status in RM shows several organizational and methodological disorders, hindering the realization of the accounting truth in different entities, though accounting complies with the IFRS. The scandal of the one-billion USD theft from three banks makes us question the quality of the banking system management, including its accounting and audit efficiency.

\section{Literature review}

The concept of the True and Fair View - TFV was first presented by the IASB Conceptual Framework and the EU Directives. Subsequently it was introduced - directly or indirectly - in the accounting regulations of several countries. However, before the concept has officially been adopted, several debates took place between the supporters and the critics of this idea. One of the TFV supporters is the British researcher Alexander D., who claimed that the financial reporting prepared based on the prudence principle (the Teleological Interpretation concept - TI) provides a less relevant information from the standpoint of the opportunity of future success, than the TFV concept. This conclusion came as a result of 
several studies on profit calculation (Alexander, Britton and lorisen, 2005).

An opposite standpoint is issued by the researchers Livne and McNichols (2009), who performed a comparative analysis of different companies, with the purpose of detecting the accounting role of TFV and TI. In their opinion, TFV led to the possibility of concealing both the level of the entity's activity, and its financial results. The divergent application of this concept in accounting also led to the occurrence of international financial scandals, like the one of Enron. The authors' general conclusion is that the TFV problem regards mainly the disclosure of profit-related information, as well as the decisions made based on it by users, especially by managers.

The TFV idea was intensely criticized by Walton (1993), according to whom "the theory and practice of financial accounting are full of odd notions, curious inconsistencies and improbable ways of approaching problems, but surely the single most bizarre notion is the British true and fair view". He considers that, in order for this notion to obtain a real meaning, it must consider the legal component of the information disclosure, as: from the standpoint of the financial disclosure practice, TFV has no meaning; the independence from the accounting rules increases the responsibility of those preparing the financial statements; accounting relies on general principles.

One topic of the debates was the older fundamental principles overriding the TFV, adopted not long ago in the Conceptual Framework and IAS 1. To this effect, several authors (Alexander and Jermakowicz, 2006; Alexander and Eberhartinger, 2009) state that these conceptions should not come into conflict, considering that both have the same objective - to meet the demand of the financial statements users for veridical information. At the same time, as the TFV is widely recommended in the Anglo-Saxon system, characterised by a higher liberalism in accounting, the concept should be adapted in the countries of the continental Europe, that rely on stricter accounting and financial reporting rules. In this context, following question should find an answer: What is the concept of the true and fair view - a fundamental request or a fundamental principle in the preparation of the financial report? The answer is obvious: this concept does not incorporate any rules regarding the preparation of the financial statements; it implies the observance of principles assuring the true and fair view.
Like any other element, it is interesting to describe the true and fair view concept in its evolution (Vladu, Matiş and Salas, 2012). The performed investigations showed that TFV: is considered a feature of the general conception of preparing the financial report; it lies in "the solving space of the conflict between the principles and the numerous accounting rules". However, with no clear definition, the TFV is only a trend, that can be compared to the American one - "the fair presentation", based on certain principles and with a different meaning.

The above mentioned issues show that:

- The TFV concept requires a legal confirmation, or else it will remain at the level of an idea;

- If, together with the prudence principle, the accounting judgment is applied, any event can be completely and truly disclosed, based on the TFV concept;

- TFV is a valuable concept of the accounting and financial reporting system, which must be investigated hereafter.

Some researchers (Covaliov, 2012) argued that the TFV concept should be applied for financial leasing agreements. In this context, it was ascertained that, as accounting and financial reporting are not merely a control instrument, but a connection meaning of business relationships, the understanding of the concept's core and its adequate application gives users the opportunity to assess financial statements as an information source of strategic value. Hence, the TFV concept allows the development of the "art" of wording legal regulations and supports the achievement of objectives.

Besides the concept of true and fair view, a particular role is played by the concept of capital maintenance. The core of this concept is that the profit calculation for the reporting period is performed by considering the time value of money and the inflation processes. Yet, as economical decision-making requires the disclosure of information on the dynamics of the capital changes based on different factors, with regard both to the capital paid by the shareholders and the capital accumulated during operation, this requirement led to the alteration of the balance sheet concept and status within the current financial reporting system (Alexander, Britton and lorisen, 2005). The opinion of Hicks (1946) was considered in this context, 
according to whom the capital dynamics can be exactly measured only in two cases: when all components change proportionately; when the price of commodities remains unchanged. According to this concept, referred to within the IFRS as the capital maintenance concept, only that part of the net assets value which overrides the increase of the general price level is recognized as profit. The remaining part of the increased net assets is regarded as a correction, ensuring the capital maintenance.

The TFV concept is strongly linked to the resource theory, enunciated in the Conceptual Framework a financial management concept, aiming to explain the achievement of sustainable competition, by efficiently using strategic resources (Rumelt, 1984). From the standpoint of the information disclosure in the financial report, emphasizing issues on resources leading to profit maximization is an essential task. In this context, the understanding of the mutual connections between the entity's resources, capacity and competitive priorities on the one hand, and its profitability on the other side, is a key issue. In this view, resources are not merely the material, but also the non-material, like the financial, human, technological, organizational and other ones. (Grant, 1991).

As known, in order to disclose information on a certain element, its identification and assessment are required. Therefore, Grant (1991) holds the view that, in applying this concept, researchers face the problem of identifying and disclosing the nonmaterial resources, whereas the solution could be to calculate the value of such assets as the difference between the fair value of the company and the replacement value of all its material resources.

\section{Research methodology}

In order to perform our study, we generally identified the factors influencing the correctness of the information disclosed in the financial report. The main criterion used consisted in the current requirements of the information users, as well as the role played by a specific factor in assuring the accounting truth within the entity. Hence, we emphasized: the accounting technique, the principles and qualitative characteristics, the accounting normalisation and the examination of the information by the auditor.

In the second stage, in order to conclude on the way in which the accounting truth is ensured, within entities located in the RM, we performed an analysis on following directions:

- the organization of the accounting technique in different types of entities;

- the adopted principles and qualitative characteristics, and their mode of operation;

- the quality and clarity of the legislative framework;

- the role of auditing in confirming the truthfulness of the data.

In the next stage, we investigated the extent to which the National Accounting Standards (NAS) comply with the IFRS, the significant deviations from these and the possibilities to improve accounting in RM.

Finally, we examined the situation of the banking system and, based on the recent dynamics of the main indicators of the Moldovan Bank of Savings (MBS), we ascertained that ignoring the control of the information on the financial position and results of the activity, including by accountants and auditors, led to significant thefts from three banks, as well as to their subsequent liquidation.

\section{The characterisation of the factors ensuring the accounting truth}

In our opinion, the accounting truth relies on several pillars, assuring its achievement (Figure 1).

Figure 1 shows that the accounting practice defined three types of "actors", who contribute to assuring the accounting truth (Colasse, 2009):

- the entity accountants and the managers, who prepare and account for the disclosed information;

- the regulators, who define the actions of the previous category; and

- the auditors, who monitor the observation of the accounting regulations. 
Figure 1. Factors assuring the accounting truth

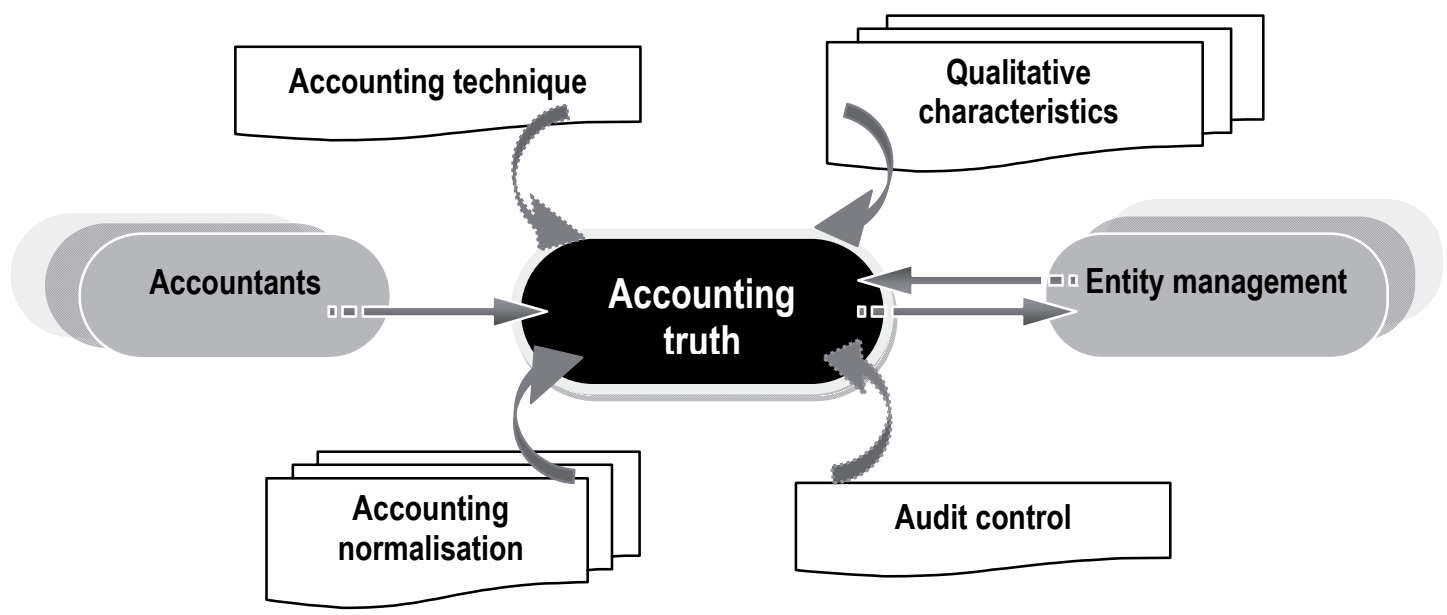

Source: Authors' processing, 2016.

The following paragraphs will detail the above mentioned.

Factor 1 - the accounting technique. In order to manage the activity, any entity needs information. The provision of financial information is the task of the accounting which, by means of its specific methods and procedures, models this process in connection with the economic magnitude of the entity's operations.

Like any other science, the accounting crossed several paradigms. One of these was the transition, at the end of the Middle Ages, from the single-entry to the doubleentry bookkeeping, presented, as known, by Luca Paciolo. This accounting system allows, based on symbols/accounts, the modelling of any type of company - simple or modern. Consequently, the double-entry bookkeeping has successfully been fulfilling the information and control function for over five centuries.

Yet the double-entry bookkeeping, as the main instrument of the accounting technique, has continuously been updated through accounts that are being changed based on the introduction of new accounting elements and economic operations. More exactly, the double-entry bookkeeping, by modelling the activity of the entity, provides the necessary data on its position, performance and financial result, disclosed in the financial report - the main information source of the economic decision-making. Though the double-entry bookkeeping allows only a limited economic analysis, the observation of its rules will largely ensure the accounting truth in any entity, as it definitely permits the examination of the correctness of the booked transactions.

\section{Factor 2 - the principles and the qualitative}

characteristics. A particular place in the preparation and disclosure of financial information is taken by the accounting principles and the qualitative characteristics of the financial information. The accounting principles involve the universal approach of practical tasks and provide the basis of accounting.

In preparing financial statements, the accountant must primarily be guided by a natural and highly important, though unofficial principle - "the entity principle", applied based on legal, financial or economic criteria. Its core idea is that accountants must define a border between the entity and its environment and distinguish it from its owners. This isolation comes mainly from legal criteria, as the entity is seen as a legal person, with its own rights and obligations. Applying "the entity principle" can be a delicate and sometimes essential matter, "turning the company into an accounting structure more or less dependent on the intervention and intention of its managers" (Colasse, 2009).

The content and the application method of the principles and qualitative characteristics are clearly enunciated in the General framework and examined in detail in literature (Țurcanu and Golocialova, 2015). We mention 
however that the method of accounting and disclosing the information in the financial report depends to a large extent on the application (or not) of the substance over form principle, while the qualitative characteristics contribute, without any doubt, to assuring the accounting truth in the entity.

Factor 3 - the accounting normalisation. A decisionrelated role in assuring the accounting truth is played by the accounting normalisation. This statement can be explained by the fact that financial information will be trusted primarily if it has been prepared based on rules, issued by specific institutions. Today, we no longer doubt the necessity of accounting regulations; yet, the issue of the regulation degree is still debated. A high number of rules hinders the development of accounting, while an excessive room for professional judgment can lead to negative consequences. The Enron case proves it once more.

Should we analyse the core and the role of the accounting normalisation, we shall find that it fulfils the following functions:

- it helps producing the necessary financial information;

- it provides the disclosed information with reliance;

- it assures the verification of the financial information, both through internal and through external control;

- it permits the settling of conflicts between contractual parties;

- it facilitates the spatial and temporal collation of data, disclosed in financial statements complying with the same regulations.

According to several researchers, a set of regulations constitute the accounting law (Richard, 2000). Such an approach is reasonable, as the accounting provisions included in specific regulations create unique requirements in the field of accounting, on state level.

Factor 4 - the audit control. It is beyond debate that, irrespective of its quality, mere regulations are not able to assure the trust of the users in the entity's financial statements. This trust is confirmed by independent experts - the auditors. Audit was born in the $19^{\text {th }}$ century, out of the need that financial information becomes a connection between the company and its external partners. This objective was reached through the examination of the financial statements by external auditors. During the $20^{\text {th }}$ century, the audit activity passed through several changes: the elaboration of the International Standards on Auditing (ISA), the performance of the external audit based on internal control, the establishment of a new auditing form - risk auditing.

The validation of the accounting data truthfulness is based on the audit opinion. The auditor, through the audit conclusion, validates or invalidates the entity's accounting truth.

\section{Accounting issues in the Repulblic of Moldova}

In the RM, the double-entry bookkeeping is prescribed by the Accounting Act RM no. 113-XVI from 27.04.2007 (Accounting Act, 2007). Art. 7 of the Act stipulates that, if the accounting regulation system does not prescribe any bookkeeping method in a specific matter, then the company is allowed to design the respective method by itself.

The Accounting Act also provides for the application of two double-entry accounting systems - a complete and a simplified one. The complete system is used for large companies and the simplified system is used for small and medium-sized companies. Yet, in fact, the National Accounting Standard "The presentation of financial statements" (NAS, 2013) does not provide for any forms of simplified financial statements for small and mediumsized companies, though their weight in the national economy amounts to ca. $75 \%$.

As mentioned above, the accounting principles and the qualitative characteristics are described in the General Framework, which actually is the basis for the current accounting theories. However, we regretfully observe that, among the regulations issued in the last years by the Ministry of Finance, no General Framework is to be found. This is a step back, compared to the first reform, based on which a similar local document had been prepared, i.e. the Conceptual Basis, showing that, in the RM, accounting theory issues are not approached, either by national specific journals, or officially. More, the process of standardization and regulation of the accounting procedures and the financial statements preparation cannot be completed, without the theoretical reasoning and the scientific interpretation of all the categories and instruments of this science. 
We can find a brief presentation of the fundamental principles and the qualitative characteristics only in the National Accounting Standard "The presentation of financial statements" (NAS, 2013). Yet, practitioners also need to know the manner in which these operate. By comparing the principles and the qualitative characteristics from the NAS with the ones presented in the General Framework, we shall notice that some of these, of major significance, are overlooked: the true and fair view, the verifiability, the timeliness, while we will not find materiality associated to relevance. And not in vain, since the Moldovan accounting does not observe substance over form. While materiality involves that information is material if its omission or misstatement may influence the decisions made by users, based on financial information (The General Framework, 2010).

At the same time, the NAS does not include any conceptual notions: the performance, associated to the calculation of the profit or loss, the recognition in the financial statements, the measurement methods, i.e. essential approaches, that should guide any accountant in practice.

In addition, the General Framework clarifies the core and the application method of the capital maintenance concept and the resource theory. Hence, it is not enough that users receive certain pieces of information, it is important that this information provides the opportunity of performing reasonable economic analyses of the data, supporting a fair decision-making.

Normalisation is conducted by a specific body, which can be differently structured in each country. For example, all the members of the US Normalisation Committee are professionals. In the EU Member states, the accounting regulation institutions consist of different interested parties, necessarily with the participation of the professional bodies. Yet, the normalisation process in these countries is supervised by the state.

In RM, the accounting normalisation is more restrictive than in the EU Member States. This state of the art is confirmed by the provisions of the Accounting Act, the NAS, the General Chart of Accounts and other regulations. The accounting regulation is conducted solely by the state, as the professional body (ACAP) does not play any part in the elaboration of the regulations, though the Accounting Act prescribes that professional bodies are part of the accounting regulation structure within the Ministry of Finance. More, according to law, professional bodies have the right to elaborate and submit for approval accounting regulation drafts (Accounting Act, 2007).

Though experts state that, following the reform, accounting complies with the IFRS, this happened directly only in public interest entities, including banks. Most entities are regulated by the NAS, which is seen as complying with the IFRS. We need to mention in this context that only 16 national standards have been elaborated; some of these include provisions of more than one IFRS, while a large part of the IFRS has not been covered by the NAS. Hence, entities often need to seek guidance in the IFRS. It was proved in literature that the impact of the financial ratios computed based on the IFRS, compared to the NAS lies between +3 and 13\% (Ghedrovici et al., 2014).

However, international regulations are too complex for the ordinary accountant, which makes the application of the accounting system and the assurance of its truth in the financial statements rather difficult. Some methodological and educational guides for practitioners, for use with the local General chart of accounts have been prepared, with the aim to explain the application of IFRS (Țurcanu and Golocialova, 2015).

At the same time, we need to clarify what accounting system is implemented in RM: the continental, or the Anglo-Saxon one. The two global accounting models were properly described by French researchers (Colasse, 2009 and Richard, 2000). Their work shows that the RM accounting system, based on its organisation, is a continental one, although, from a methodological point of view, it complies with the IFRS, which are actually aligned to the Anglo-Saxon accounting system. Hence, the specific features of the accounting system in the RM are the following:

a. The regulation through banks, as these dominate the investment and financing process of the national economy. This factor leads to multiple interested parties of the information disclosed by the entities;

b. The prevalence of the legal over the economic reality;

c. The multiple accounting regulations, leaving only limited room for professional judgment;

d. The strong connection between accounting and tax; the accounting benefit is to a certain extent restrained by tax rules;

e. The measurement at historical cost, in the context of the prudence principle, to the detriment of the fair value. 
To the above specified shortages of the RM accounting system, some researchers add the following:

- The long and slow reformation of accounting (almost 20 years), due to the lack of a clear and long-termed conceptual framework (Alexander and Ghedrovici, 2013);

- The accounting reform should have been oriented towards business performance and privatisation; it requires a closer collaboration between ACAP and the governmental bodies, for the adaptation of the new accounting standards (Armitage, Neider and Shelaru);

- The IFRS and the NAS include controversial regulations; for example, with regard to the impairment of fixed assets, a comparison between non-comparable ratios should be performed (Bucur and loniță, 2016).

In the 2013 Report of the World Bank on the accounting and auditing quality in the RM, several methodological and organisational remarks are included, like: the lack of the General Framework, of a NAS on consolidated financial statements, the need for a revision of the Accounting Act etc. (World Bank, 2013).

In performing audit engagements, auditors in RM are guided by the Auditing Act no. 61-XVI from 16.03.2007 (the Auditing Act, 2007), while the audit methodology complies with the International Standards on Auditing (ISA). Audit is mandatory, according to law, only in large and public interest entities.

A further problem associated to audit regards the supporting documents provided for examination by the audited entity. If the entity manager manipulates these documents, the auditor should apply adequate procedures for identifying those documents which were not delivered. As a consequence, the magnitude of the underground economy would decrease. Much here depends on the ethics of the manager, the accountant and even the auditor.

\section{Consequences of ignoring the control of financial information}

As the banking system is a significant component of the national economy, as well as an extremely sensitive sector during financial crises, we should also investigate the accounting truth and the role of auditing in this field. We need to mention that both accounting, and auditing in the banking system show significant particular features, related to the credit provision, various risks, the responsibility of the managers and of the employees in cash-based transactions, which often involve enormous amounts of money.

The recent famous scandals in the RM banking system, involving thefts of one billion US dollars from three commercial banks (The Savings Bank, The Social Bank and Unibanc), lead to multiple prosecutions, generated debates among analysts, as well as a strong dissatisfaction of the population. Currently, the guilty parties are identified and arrested, the money is sought and paid back, though no one is wondering: what kind of accounting has been practiced in these banks, what kind of auditing has been performed in the banking system, since such enormous damage was caused both to the state, and the banking system and it ended only in the liquidation of the involved banks?

In the case of the American company Enron, back in 2003, when losses amounted to trillions of dollars, economists contributing to literature also blamed it on the accounting, while the famous auditing firm Arthur Andersen, which presented a deficient opinion on the information disclosed by Enron, lost its licence and was subsequently liquidated. We may wonder, what adequate measures will be taken with regard to the theft of the century, from RM?

The irregularities in the banking system have been on the increase since 2012, when certain private shareholders or the government manipulated the majority of shares for the own benefit. This was the case of The Moldovan Savings Bank (Banca de Economii a Moldovei - BEM). Hence, up to 2013, the state held $56 \%$ of the bank's shares; the shareholding subsequently decreased to $33 \%$, following the additional issue of shares. The bank had already started to act for the benefit of the private shareholders, with well-known consequences. In support of this fact, as well as of other proofs of the deteriorated financial position of the BEM, Table 1 summarizes the financial indicators of the bank for the years 2011, 2013, 2015.

It should be mentioned that ignoring certain theoretical positions and disclosure requirements for the financial information, as prescribed by the General Framework, can lead to serious consequences in performing the operational analysis of the entity's financial and 
economic position. For example, the concept of the capital maintenance is highly significant, primarily with regard to commercial banks. According to this concept, the capital maintenance is achieved only if the amount of net assets at the end of a period is equal to or exceeds the amount at the beginning of the period. Provided that the accountants and analysts of the BEM had continuously followed the level of this indicator, the bank would not have gone bankrupt. In 2012, compared to 2011, the amount of net assets (equity) remained unchanged, but up to the end of 2014, it lowered by 147 million lei and up to 30.06 .2015 , by 198 million lei.

\begin{tabular}{|c|c|c|c|c|}
\hline Indicators & MU & 31.12.2011 & 31.12.2013 & 30.06 .2015 \\
\hline Total assets & thousand lei & $5,841,010$ & $8,532,765$ & $14,556,358$ \\
\hline Total normative equity & thousand lei & 828,209 & 555,032 & 276,570 \\
\hline Shareholders' equity & thousand lei & 117,337 & 197,587 & 197,587 \\
\hline Liquid assets & thousand lei & $2,618,948$ & $5,636,926$ & 494,810 \\
\hline Deposits & thousand lei & $4,404,200$ & $6,426,337$ & $4,450,198$ \\
\hline Credits & thousand lei & $2,866,008$ & $1,221,578$ & $1,321,300$ \\
\hline Profit (loss) & thousand lei & 28,727 & 35,405 & $-166,843$ \\
\hline Credit impairments & thousand lei & 394,668 & 468,870 & 541,842 \\
\hline $\begin{array}{l}\text { Adequacy of the weighted capital to risk (Minimum } \\
\text { level } 16 \% \text { ) }\end{array}$ & $\%$ & 32.96 & 3,22 & 2.21 \\
\hline Equity loss & $\%$ & - & -34.51 & -4.40 \\
\hline Share of foreign investors in the shareholders' equity & $\%$ & 10.13 & 17.63 & 42.50 \\
\hline Bad loans /Total loans & $\%$ & 31.86 & 58.42 & 79.68 \\
\hline Return on assets (ROA) & $\%$ & 0.52 & 0.54 & -2.31 \\
\hline Return on equity (ROE) & $\%$ & 3.93 & 3.97 & -47.18 \\
\hline Net interest income/total income & $\%$ & 37.40 & 6.95 & -6.43 \\
\hline Long term liquidity (Minimum level 1) & $\%$ & 0.65 & 0.29 & 0.31 \\
\hline Current liquidity (Minimum level 20) & $\%$ & 44.94 & 66.00 & 87.70 \\
\hline
\end{tabular}

Source: Authors' processing.

The deterioration of the financial position of the three banks mentioned above shows that the financial and the internal audit in the banking system faced severe difficulties. A group of individuals was preparing, in 2013, the take-over of these banks. Between 2012-2014, the financial position of the three banks worsened, questionable credits and liabilities of 13.8 bill. lei were recorded. Yet, the losses of the state increased because, in 2014, the National Bank of Moldova granted the three banks a state aid for rehabilitation, amounting to 10 bill. lei. It is however well-known that the banks were liquidated in 2015. In commercial banks, corruption had been in place for a while: even since 2010-2011, the crediting rules were frequently broken at the MBS, with consequent losses of 244 bill. lei. At the same bank, the CFO and the depositary deputy manager stole 7 mill. US dollars. Accordingly, the missing internal and external control at MBS lead to the sudden deterioration of the main indicators (see Table 1) and the bank went bankrupt. More, the weight of the bad loans in total loans reached $79.7 \%$ in 2015.

The Parliament commission, together with the American auditing firm Kroll, in charge with the investigation of the three banks, have so far presented two preliminary reports. Yet, the results of the report are classified, based on a Parliament decision, so that neither the guilty parties, nor the role played by the financial audit in this matter, have so far been made public.

Though the quality of auditing practice is problematic and its effectiveness is hard to measure, the external audit can however be assessed based on the results of the accounting discipline at the audited entity and, to a certain extent, based on the efficiency of its activity. The British auditing firm Grant Thornton had been rendering services for the BEM and other Moldovan banks since 2010 and had issued unqualified opinions for five years, 
during which the entity was on the fall; still, the audit is not held accountable for it. In this context, what is the audit supervision framework for? In the case of banks, significant shortages associated to the share management can be observed, even on the part of the National Bank of Moldova (Banca Națională a Moldovei - BNM).

\section{Bonclusions}

Studies reveal that the accounting from RM, as an information system and a control instrument, fulfils its functions according to the Accounting Act. By modelling the activity of the entity, through the double-entry bookkeeping and the accounts, the financial report can be prepared and suits the needs of all users. At the same time, the law should mandatorily prescribe the publication of the financial statements of all entities (except for the small ones), in order to assure the transparency of the data.

The principles and the qualitative characteristics of the financial information, which should underlie the preparation of the financial statements, are presented by the IASB General Framework (2010). However, they are missing from the accounting regulation system of RM. Hence, the theoretical quality of the local accounting is lowered. At the same time, it should be mentioned that the accounting truth is enhanced by the application of substance over form, which is however not recommended to local entities.

We ascertained that normalisation has an essential contribution to disclosing the accounting truth, it directs the behaviour of the managers and it assures the spatial and temporal comparability of data. Still, normalization cannot be absolutely faultless; managers can take advantage of its shortages and manipulate information in the preparation of the financial report. An illustration thereof was the case of the three Moldovan commercial banks, where the shareholdings were altered against the state. Yet, the regulations in RM should give accountants room for the application of the professional judgment, in order to create a true and fair view.

The accounting methodology in RM is guided by the IFRS, as well as by NAS, in compliance with the IFRS. Controversial rules, which sometimes complicate the preparation of the financial statements, can however be observed. At the same time, the NAS do not recommend measurement methods, applied in advanced economies; some of their provisions have a tax orientation.

According to international and European regulations, no accounting information is considered reliable, unless it has been audited. Only after its fairness has been confirmed, can information serve as a basis for proper decision-making or, in other words, the accounting truth can be certified. However, auditing in RM is mandatory only in large and public interest entities.

Based on the study, instances were identified when the auditor presented an unqualified opinion on the data disclosed in the financial statements, while serious misconduct was in place in the economic and financial activity of the audited entity. This was the case of the British auditing firm "Grant Thornton", which provided services for certain commercial banks from Moldova, including the three banks that were finally liquidated by the government, over a period of five years.

We consider that the law and jurisprudence of the RM should prescribe serious penalties for accountants who overlook fraud in the disclosure of information, as well as for auditors who issue defective reports.

Currently, the main regulations such as The Accounting Act (2007) and The Auditing Act (2007) are aligned only to international standards. However, as the RM entered into commitments associated to the Association Agreement EU-RM, through the Government Decision no. 713 from 12.10.2015 (The Government Decision, 2015), the National Action Plan for the implementation of the agreement prescribes the preparation of following documents, in the fourth quarter of 2016:

1. The Accounting Act, in compliance with the provisions of the Directive 2013/34/UE, on the annual financial statements, consolidated financial statements and related reports of certain types of undertakings;

2. The Auditing Act, in compliance with the provisions of the Directive 2006/43/UE, on statutory audits of annual accounts and consolidated accounts.

The new acts will aim to introduce nationally relevant international standards, as well as to gradually harmonize the RM and the EU accounting and auditing regulations. 


\section{REFERENCES}

1. Alexander, D. and Eberhartinger, E. (2009), A True and Fair View in the European Union, European Accounting Review, vol. 18, no. 3, pp. 571-594, DOl: http://dx.doi.org/10.1080/09638180902784405.

2. Alexander, D. and Ghedrovici, O. (2013), Evolution of Accounting in Moldova: Some Reflections About the Importance of Historical and Cultural Factors, în Albu, C.N. şi Mustață R.V. (ed.) Accounting in Central and Eastern Europe (Research in Accounting in Emerging Economies, Volume 13) Emerald Group Publishing Limited, pp. 121-142, DOI: http://dx.doi.org/10.1108/S14793563(2013)0000013010.

3. Alexander, D. and Jermakowicz, E. (2006), A True and Fair View of the Principles/Rules Debate, Abacus, vol. 42, no. 2, pp. 132-164, DOl: http://dx.doi.org/10.1111/j.14676281.2006.00195.x.

4. Alexander, D., Britton, A. and lorisen, E. (2005), International Financial Reporting Standards: from theory to practice, Moscow: Vershina.

5. Armitage, J., Neider, M. and Shelaru, M. (2007), Accounting Reform in the Republic of Moldova, International Business and Economics Research Journal, vol. 2, no.4, pp. 92-95, DOl: http://dx.doi.org/10.19030/iber.v2i4.3785.

6. Bucur, V. and loniță, N. (2016), Prudența, provizioanele şi adevărul în deprecierea activelor, în Paradigma contabilității şi auditului: realități naționale, tendințe regionale şi internaționale, Chişinău: ASEM, pp. 29-32.

7. Colasse B. (2009), Fundamentele contabilității (translation from French by N. Tabără), laşi: TipoMoldova.

8. Colasse, B. (1997), The French notion of the image fidele: the power of words, European Accounting Review, vol. 6, no. 4, pp. 681-691, DOl: http://dx.doi.org/10.1080/09638189700000009.

9. Covaliov, V. (2012), True and Fair Concept in Accounting: Definition and Application, Vestnik of St. Petersburg University, vol. 5, no. 2, pp. 3-12.

10. Directive 2013/34/EU of the European Parliament and of Council of 26 June 2013 on the annual financial statements consolidated financial statements and related reports of certain types of undertakings, [online], Available at: http://eurlex.europa.eu/legalcontent/EN/TXT/?uri=CELEX\%3A32013L0034, [Accessed on June 12, 2016].

11. Ghedrovici, O., Mihaila, S., Erhan, L., Bîrca, A. (2014) Transition to IFRS in the Republic of Moldova: general and practical aspects, Accounting and Management Information System, vol. 13, no. 2, pp. 259-280.

12. Grant, R. (1991), The Resource-Based Theory of Competitive Advantage: Implications for Strategy Formation, California Management Review, vol. 33, no. 3, pp. 114-135, DOl: http://dx.doi.org/10.2307/41166664.

13. Gray, S.J., Coenenberg, A.G. and Gordon, P.D. (1993), International group accounting: Issues in European Harmonization, London: Routlege.

14. Hicks, J. (1946), Value and Capital, Oxford: Clarendon Press. ("Reprinted as Income" in Parker and Harcourt, 1969).

15. Hotărârea Guvernului nr. 713 din 12.10.2015 privind modificarea şi completarea în Hotărârea Guvernului nr. 808 din 07.10.2014 cu privire la aprobarea Planului național de acțiuni pentru implementarea Acordului de Asociere Republica Moldova - Uniunea Europeană în perioada 20142016 [Government Decision no. 808 from 07.10.2014 on the approval of the National Action Plan for the implementation of the Association Agreement between the Republic of Moldova and the European Union, for the period 2014-2016], [online], Available at: httl://www.lex.justice.md/md/ 361471/, [Accessed on June 12, 2016].

16. Legea contabilității nr. 113-XVI din 27 Aprilie 2007, cu modificările şi completările ulterioare [The Accounting Act No. 113-XVI from April 27, 2007, with all subsequent completions and changes], [online], Available at: httl://www.mf.gov.md/actnorm/contabil/lawcontabil/, [Accessed on June 12, 2016].

17. Legea privind activitatea de audit nr. 61-XVI din 16.03.2007 republicată [The Auditing Act No. 61- 
XVI from 16.03.2007, republished], [online], Available at: httl://www.mf.gov.md/actnorm/ audit/1laws /, [Accessed on June 12, 2016].

18. Livne, G. and McNichols, M. (2009), An Empirical Investigation of the True and Fair Override in the United Kingdom, Journal of Business Finance \& Accounting, vol. 36, no. 1-2, pp. 1-30, DOI: http://dx.doi.org/10.1111/j.1468-5957.2008.02112.x .

19. Ministerul Finanțelor al Republicii Moldova, Cadrul general conceptual pentru raportarea financiară [The Conceptual Framework for Financial Reporting], [online] Available at: http:// http://www.mf.gov.md/actnorm/contabil/standartrap ort/ [Accessed on June 12, 2016].

20. Ordinul Ministerului Finanțelor 109 din 19.12.2008 privind accesarea şi publicarea Standardelor Internaționale de Rapoarte Financiară [The Order of the Ministry of Finance No. 109 from 19.12.2008 on the access to and publishing of the International Financial Reporting Standards], [online], Available at: httl:// www.mf.gov.md/actnorm/contabil/ standartraport, [Accessed on June 12, 2016].

21. Richard, J. (2000), Accounting: Theory and Practice, Moscow: Financy and statistica.

22. Rumelt, R.P. (1984), Towards a Strategic Theory of the Firm, Competence Strategic Management, Lamb, R.B. (ed.) Englewood Cliffs, Nj: Prentice Hall, pp.556-570.

23. Standardele Internaționale de Raportare Financiară (SIRF) [The International Financial Reporting Standards], [online], Available at: httl://www.mf.gov.md/actnorm/contabi//standartrap ort/, [Accessed on June 12, 2016].
24. Standardele Naționale de Contabilitate, aprobate prin Ordinul Ministerului Finanțelor nr. 118 din 06.08.2013 [The National Accounting Standards, approved by Order of the Ministry of Finance No. 118 from 06.08.2013], [online], Available at: httl://www.mf.gov.md/actnorm/contabil/standartnew I, [Accessed on June 12, 2016].

25. The magazine "Logos Press”, for the years 2011, 2013, 2015: information on banking activities, [online], Available at: httl://www.logos.press.md/ [Accessed on June 12, 2016].

26. Turcanu, V. and Golocialova I. (2015), Raportarea financiară conform standardelor internaționale, Chişinău: ACAP.

27. Vladu, A.B., Matiş, D. and Salas, O.A. (2012), True and Fair View and Creative Accounting Conceptual Delimitations Based on Papineau's Tree Methodology, Annales Universitatis Apulensis Series Economica, vol. 14, no. 1, pp. 104-115.

28. Walton, P. (1993), Introduction: The True and Fair View in British Accounting, European Accounting Review, vol. 2, no. 1, pp. 49-58, DOl: http://dx.doi.org/10.1080/09638189300000003.

29. World Bank (2013) Report on the Observance of Standards and Codes on Accounting and Auditing - Moldova, [pdf] Available at: http://wwwwds.worldbank.org/external/default/WDSContent Server/WDSP/IB/2013/09/27/000333037_201309 27110449/Rendered/PDF/ACS41110ROSCOE00 x0379834B00PUBLIC0.pdf, [Accessed on June 14, 2016]. 